Violetta Korporowicz

\title{
ALKOHOLIZM, PROSTYTUCJA, ZAKAŻENIA HIV I AIDS, NARKOMANIA JAKO FORMY WYKLUCZENIA SPOŁECZNEGO (W ŚWIETLE BADAŃ)
}

\section{Wprowadzenie}

Przez wykluczenie społeczne należy rozumieć stan czy raczej proces uniemożliwiający lub znacznie utrudniający jednostce lub grupie pełnienie zgodnie z prawem ról społecznych, korzystanie z dóbr publicznych i infrastruktury społecznej, gromadzenie zasobów i zdobywanie dochodów w godny sposób. ${ }^{1}$ Wykluczenie to dotyka częściej osób, które nie zostały wyposażone przez rodzinę w kapitał życiowy umożliwiający im prawidłowe funkcjonowanie w społeczeństwie, zdobycie odpowiedniego poziomu wykształcenia, aby znaleźć zatrudnienie, założenie rodziny, dostosowywanie się do zmieniających się warunków społecznych i ekonomicznych. $\mathrm{Na}$ występowanie, a następnie pogłębienie się zjawiska wykluczenia społecznego mogą wpływać liczne aspekty życia społecznego, którymi są bez wątpienia np. alkoholizm, prostytucja czy narkomania.

W opracowaniu postawiono dwa cele. Jednym $z$ nich jest analiza przyczyn i rozwoju negatywnych zjawisk społecznych takich jak np. alkoholizm, narkomania czy prostytucja. Drugim celem jest wskazanie, że w wyniku rozwoju tych niekorzystnych zjawisk społecznych może nastąpić poszerzenie zjawiska wykluczenia społecznego.

\section{Zakres wykluczenia społecznego - pojęcia wstępne}

Termin wykluczenie (marginalizacja) społeczne określa zjawisko lub sytuację, w której następuje niepodejmowanie uczestnictwa w życiu społecznym. Wykluczenie społeczne jest zjawiskiem wielowymiarowym i oznacza niemożność uczestnictwa

\footnotetext{
${ }_{1}$ Narodowa Strategia Integracji Społecznej dla Polski, Ministerstwo Pracy i Polityki Społecznej, Warszawa 2003, s. 23.
} 
w życiu gospodarczym, politycznym, kulturowym. Następuje ono w wyniku ograniczenia dostępu do dóbr, instytucji, łamania praw człowieka czy deprywacji potrzeb.

Wykluczenie społeczne dotyczy poszczególnych osób, rodzin lub całych grup ludności, które żyją w ubóstwie ekonomicznym, bądź zostają dotknięte niekorzystnymi zjawiskami społecznymi. W wyniku wykluczenia dana jednostka czy grupa nie może w pełni uczestniczyć w działaniach obywateli danego społeczeństwa, przy czym ograniczenie to nie wynika $\mathrm{z}$ ich osobistych wyborów, ale jest narzucone z zewnątrz.

W takim podejściu ważna jest odpowiedź na następujące pytania:

- Co lub kto wyklucza?

- Kto jest wykluczany?

- Z jakich aspektów życia społecznego wykluczana jest dana jednostka?

Jednostka jest społecznie wykluczona w opinii Center for Analysis of Social Exclusion, jeżeli: mimo że jest ona pod względem geograficznym członkiem społeczeństwa oraz chce uczestniczyć w życiu społecznym, nie może tego zrobić z powodów będących poza jej kontrolą. ${ }^{2}$

Jednostkami i grupami społecznymi najbardziej narażonymi na wykluczenie społeczne w świetle Human Development Report są: osoby niepełnosprawne, chore psychicznie, uzależnione, długotrwale bezrobotne, ludzie opuszczający zakłady karne i poprawcze, kobiety samotnie wychowujące dzieci, ofiary patologii życia rodzinnego, ludzie o niskich kwalifikacjach zawodowych, osoby starsze, samotne, bezdomne, dzieci i młodzież ze środowisk zaniedbanych oraz wychowujące się poza rodziną, imigranci oraz członkowie mniejszości narodowych. ${ }^{3}$ Prawdopodobieństwo dotknięcia wykluczeniem zwiększa się, gdy jednostka posiada kilka cech charakterystycznych $\mathrm{z}$ wymienionych grup jest (np. uzależniona, długotrwale bezrobotna czy chronicznie chora). ${ }^{4}$

Czynnikami wpływającymi na powiększanie się liczby osób i grup społecznych dotkniętych wykluczeniem jest cały katalog zjawisk, do których można zaliczyć np.:

- ubóstwo,

- analfabetyzm,

- bezrobocie długoterminowe,

- chorobę. ${ }^{5}$

2 R. Levitas, Ch. Pantazis, E. Fahny, D. Gordon, E. Lloyd, D. Patsios, The multi-dimensional analysis of social exclusion, University of Bristol, London 2007, s. 145-146, www.bris.ac.uk/poverty/Social\%20 (dostęp 16.07.2011).

${ }^{3}$ http://hdr.undp.org/en/reports (dostęp 13.08.2011).

4 Z. Dach, Ekonomiczno-społeczne problemy transformacji systemowej w Polsce, Wydawnictwo Ekonomiczne w Krakowie, Kraków 2007, s. 90-91.

${ }_{5}$ Zarzadzanie zasobami ludzkimi w warunkach nowej gospodarki, red. Z. Wiśniewski, A. Pocztowski, Oficyna Ekonomiczna, Kraków 2004, s. 8. 
W przypadku wykluczenia społecznego jednostek czynnikami mającymi na to największy wpływ są bezrobocie i ubóstwo. Jeżeli dochodzi do koncentracji tego typu ludności w przestrzeni geograficznej, może wówczas pojawiać się specyficzna subkultura ubóstwa oraz wytwarzać się podklasa (underclass), czyli osoby utrzymujące się z zasiłków i pomocy społecznej, a w skrajnych przypadkach składająca się z przestępców czy recydywistów. ${ }^{6}$ Są to ludzie, którzy z reguły nie posiadają wykształcenia i nie pracują. Do podklasy należą też ludzie bezdomni, żebracy, ubodzy alkoholicy i narkomani oraz złodzieje, ludzie objęci programami społecznymi, nielegalni imigranci i członkowie band, np. młodzieżowych.?

Wykluczenie społeczne jest trudne do zmierzenia. Trudność ta wynika $\mathrm{z}$ faktu licznych aspektów życia społecznego, które ono dotyka. To stwarza problem z ustaleniem stałego katalogu zmiennych w celu określenia tego zjawiska w ramach nie tylko jednego regionu, a przede wszystkim w całym kraju czy nawet między krajami.

Najbardziej znanym współcześnie pośrednim sposobem badania wykluczenia społecznego jest metoda stosowana przez United Nations Development Programme (UNDP) na rzecz badania rozwoju społecznego. Została ona przedstawiona w Human Development Report. ${ }^{8}$ Ze względu na duże różnice pomiędzy krajami rozwijającymi się a krajami rozwiniętymi skonstruowano dwa odmienne wskaźniki ubóstwa społecznego (human poverty index - HPI): HPI-1, HPI-2. HPI-1 jest przeznaczony dla krajów rozwijających się, a HPI-2 dotyczy krajów rozwiniętych. ${ }^{9}$

HPI jest podstawą badania rozwoju intelektualno-ekonomicznego społeczeństwa, uważa się go za bardziej miarodajny wskaźnik niż PKB per capita czy wskaźnik rozwoju społecznego (human development index - HDI), bowiem w przypadku HPI brane są pod uwagę nie tylko zarobki w odniesieniu do struktury demograficznej, ale porównanie do stopnia ubóstwa i poziomu analfabetyzmu czy długoterminowego braku zatrudnienia. Należy jednak pamiętać, że za pomocą HPI możemy tylko pośrednio wnioskować o stopniu wykluczenia społecznego, jako że choć np. bezrobocie długoterminowe czy analfabetyzm są czynnikami generującymi wykluczenie, nie są to wszystkie czynniki wpływające na samo zjawisko, a tym bardziej nie jest to wskaźnik określający dokładnie poziom wykluczenia społecznego.

\footnotetext{
6 Specyfiką podklasy są wzory zachowań i systemy wartości, które często podlegają dziedziczeniu w następnych pokoleniach. Pod wpływem marginalizacji na obszarach miejskich możliwe jest wytwarzanie się slamsów.

7 Z. Bauman, Zawrotna kariera ,podklasy”, http://www.tezeusz.pl/cms/tz/index.php?id

8 http://hdr.undp.org/en/reports/

${ }^{9}$ HPI-1 skonstruowany jest w oparciu o prawdopodobieństwo, że noworodek nie dożyje 40. roku życia, stopę analfabetyzmu u dorosłych oraz deprywację standardu życia (odsetek ludzi pozbawiony stałego dostępu do wody oraz odsetek dzieci z niedowagą). HPI-2 mierzy wykluczenie społeczne na podstawie następujących wskaźników: prawdopodobieństwa, że przeciętne dalsze trwanie życia będzie niższe niż 60 lat, stopy analfabetyzmu dorosłych, odsetka ludności żyjący poniżej granicy ubóstwa.
} 
W ramach Unii Europejskiej prowadzone są też badania i analizy dotyczące zasięgu społecznego zróżnicowania ubóstwa. Analiza ta nazwana została Europejskim badaniem dochodów i warunków życia (EU Statistics on Income and Living Condition - EU SILC). Za zagrożone ubóstwem według EU SILC uważa się osoby żyjące w gospodarstwach domowych, których dochód do dyspozycji jest niższy od granicy ubóstwa ustalonej na poziomie $60 \%$ mediany dochodu w danym kraju. ${ }^{10}$

Jak wynika $\mathrm{z}$ tabeli 1, krajami o najniższym poziomie ubóstwa społecznego na świecie są Szwecja i Norwegia. Z krajów pozaeuropejskich - Kanada, Japonia i Australia. Stany Zjednoczone plasują się dopiero na 17. miejscu.

Tabela 1. Wskaźnik ubóstwa społecznego według krajów (2009 rok, w \%)

\begin{tabular}{|c|l|c|c|c|c|c|}
\hline Miejsce & Kraj & HPI-2 & $\begin{array}{c}\text { Prawdopodobieństwo } \\
\text { śmierci przed 60. } \\
\text { rokiem życia }\end{array}$ & $\begin{array}{c}\text { Funkcjonalni } \\
\text { analfabeci }\end{array}$ & $\begin{array}{c}\text { Długotrwate } \\
\text { bezrobocie }\end{array}$ & $\begin{array}{c}\text { Odsetek ludności } \\
\text { uzyskujący poniżej 50\% } \\
\text { mediany dochodów }\end{array}$ \\
\hline 1 & Szwecja & 6,3 & 6,7 & 7,5 & 1,1 & 6,5 \\
\hline 2 & Norwegia & 6,8 & 7,9 & 7,9 & 0,5 & 6,4 \\
\hline 3 & Holandia & 8,1 & 8,3 & 10,5 & 1,8 & 7,3 \\
\hline 4 & Finlandia & 8,1 & 9,4 & 10,4 & 1,8 & 5,4 \\
\hline 5 & Dania & 8,2 & 10,3 & 9,6 & 0,8 & 5,6 \\
\hline 6 & Niemcy & 10,3 & 8,6 & 14,4 & 5,8 & 8,4 \\
\hline 7 & Szwajcaria & 10,7 & 7,2 & 15,9 & 1,5 & 7,6 \\
\hline 8 & Kanada & 10,9 & 8,1 & 14,6 & 0,5 & 11,4 \\
\hline 9 & Luksemburg & 11,1 & 9,2 & - & 1,2 & 6,0 \\
\hline 10 & Austria & 11,1 & 8,8 & - & 1,3 & 7,7 \\
\hline 11 & Francja & 11,2 & 8,9 & - & 4,1 & 7,3 \\
\hline 12 & Japonia & 11,7 & 6,9 & - & 1,3 & 11,8 \\
\hline 13 & Australia & 12,1 & 7,3 & 17,0 & 0,9 & 12,2 \\
\hline
\end{tabular}

Źródło: http://hdr.undp.org/en/statistics/indices/hpi/ (dostęp 18.08.2011).

Z badań Eurostatu przeprowadzonych w ramach EU SILC 2008, w których zbierano generalnie informacje o sytuacji dochodowej gospodarstw domowych, wynika, że w sferze ubóstwa żył w tym czasie co szósty obywatel Unii Europejskiej (17\% osób); np. Czechach - do 9\% obywateli, w Słowacji i Holandii - do 11\%, w Rumunii - do 23\%, na Łotwie - do $26 \%$.

W Polsce wskaźnik zagrożenia ubóstwem był taki jak średnia dla 27 krajów Unii i wyniósł 17\%. Jednocześnie jednak Polska zaliczała się do grona krajów

${ }^{10} \mathrm{http} / / /$ epp.eurostat.ec.europa.eu/portal/page/portal/statistics/themes (dostęp 21.03.2011). 
charakteryzujących się stosunkowo niskim poziomem ubóstwa. Wartość granicy ubóstwa dla gospodarstwa jednoosobowego wynosiła w Polsce w 2008 roku około 9,4 tys. zł rocznie, a po uwzględnieniu różnic cen w krajach Unii - 3,9 tys. zł. ${ }^{1}$

Negatywne skutki wykluczenia społecznego, którego podstawową przyczyną jest ubóstwo, ograniczają możliwość rozwoju ekonomicznego. Skala wykluczenia w Polsce jest również wielka i dotyczy nie tylko osób bezdomnych czy bezrobotnych, ale też osób nieuczestniczących w życiu społeczno-gospodarczym. Myśląc o prawidłowym rozwoju, należy ograniczać nie tylko skutki, ale samo zjawisko wykluczenia, a to możliwe jest do zrealizowania m.in. poprzez tworzenie planów pomocowych czy programów walki z wykluczeniem. Programy te odnoszą się do przeciwdziałania mechanizmom wykluczenia społecznego, co powinno się ściśle wiązać z edukacją społeczną przede wszystkim młodzieży, chociaż trudno pomijać osoby dorosłe. Skutki te łagodzone są przez działania doraźne.

\section{Formy wykluczenia społecznego}

\subsection{Alkoholizm}

Alkoholizm (uzależnienie od alkoholu) - choroba polegająca na utracie kontroli nad ilością spożywanego alkoholu. Aby mówić o chorobie alkoholowej, muszą wystąpić minimum trzy $\mathrm{z}$ następujących objawów: silna natrętna potrzeba spożywania alkoholu, upośledzona zdolność kontrolowania picia alkoholu, objawy abstynencyjne, np.: drżenia mięśniowe, nadciśnienie tętnicze, bezsenność, rozszerzenie źrenic, zmieniona tolerancja alkoholu, narastające zaniedbywanie alternatywnych do picia przyjemności, zachowań i zainteresowań, picie alkoholu mimo oczywistej wiedzy o jego szczególnej szkodliwości dla zdrowia pijącego. ${ }^{11}$

W ciągu ostatniego stulecia spożycie alkoholu na świecie wzrosło. Nadużywanie alkoholu jest jednym z najważniejszych problemów zdrowotnych. Szacuje się, że np. w USA nadużycie alkoholu powoduje 100 tys. zgonów rocznie, co czyni go trzecią przyczyną umieralności (po paleniu papierosów i schorzeniach związanych z niewłaściwą dietą oraz siedzącym trybem życia). Choć dokładną liczbę osób uzależnionych od alkoholu trudno oszacować, uważa się, że tylko w Stanach Zjednoczonych

11 V. Korporowicz, Równość płci? Między fikcja a prawdą. Wspótczesne problemy demograficzne. Rzeczywistość i mity. Ujęcie krajowe, regionalne i globalne, red. nauk. J. Osiński, Oficyna Wydawnicza SGH, Warszawa 2011, s. 473. 
mieszka 14-20 mln osób, które są chore w wyniku nadużywania alkoholu. Ocenia się, że 40\% Amerykanów zetknęło się ze skutkami choroby alkoholowej u któregoś z członków rodziny. Co roku 12 tys. dzieci pijących matek pozbawione zostaje możliwości pełnego fizycznego i intelektualnego rozwoju, rodząc się z objawami zespołu alkoholowego, który nabywają już w życiu płodowym. To powoduje, że w ciągu życia cierpią na poważne zaburzenia somatyczne i psychiczne. ${ }^{12}$

W Polsce około 4,5 mln osób nadużywa alkoholu, w tym 600-900 tys. jest uzależnionych i wymaga leczenia. W 2009 roku mężczyźni pili alkohol 4,5 razy częściej niż kobiety (sześć lat wcześniej ponad 8-krotnie częściej). Mężczyźni piją najwięcej między 20. a 30.rokiem życia i 8 razy częściej uzależniają się niż kobiety. Rośnie także liczba uzależnionych kobiet. Jeszcze przed kilku laty nie przekraczały one liczby $3 \%$ wśród wszystkich alkoholików, obecnie mówi się o 8-10\%, przy czym u kobiet do uzależnienia dochodzi szybciej i w młodszym wieku. ${ }^{13}$

Najwyższe spożycie alkoholu w Polsce notowano w latach 1979 i 1980, kiedy na jednego statystycznego mieszkańca przypadało 8,51 100\% alkoholu. W późniejszych latach nastąpił spadek do poziomu około 6,5 l, jednak równocześnie oceniano, że faktyczne spożycie alkoholu może być wyższe o $30 \%$, o tyle szacuje się nielegalną produkcję alkoholu. W latach dziewięćdziesiątych spożycie zaczęło znowu wzrastać i ocenia się, że obecnie wynosi ono około 101 100\% alkoholu na mieszkańca. ${ }^{14}$

Istotnym problemem związanym ze spożyciem alkoholu jest jego picie przez młodzież. Zjawisko to występuje w większości krajów, nie tylko europejskich. „Przodują” w tym zwłaszcza Dania, Wielka Brytania i Grecja; Polska zajmuje dziewiąte miejsce. Także pod względem upijania się polska młodzież nie jest na pierwszym miejscu wśród krajów naszego kontynentu. Przodują tu także Dania, Wielka Brytania i Irlandia. Mimo to w Polsce aż 10\% polskich uczniów twierdzi, że w jednym miesiącu upija się przynajmniej trzy razy. W Danii przyznaje się do tego 30 \% uczniów, w Irlandii - $24 \% .^{15}$

Wagę problemu związanego $\mathrm{z}$ alkoholizmem w Polsce potwierdzają liczne badania. Jedno z nich dotyczy spożycia alkoholu wśród studentów pierwszego i trzeciego roku studiów różnych uczelni w 2000 roku. Wykazało ono, że przeważającą grupę badanych (30,5\%) stanowiły osoby w wieku 20 lat. Natomiast tylko 6\% respondentów nigdy nie piło alkoholu. Znaczna część badanej młodzieży - 38,7\% - stwierdziła,

12 P.G. O'Connor, R.S. Schottenfeld, Patients with alcohol problems, „New England Journal of Medicine” 1998 Vol. 338, Nr 9.

13 Diagnoza społeczna 2009: warunki i jakość życia Polaków. Raport, red. J. Czapiński, Centrum Rozwoju Zasobów Ludzkich, Warszawa 2009, s. 49.

${ }^{14} \mathrm{http} / / / \mathrm{cc} . \mathrm{msnscache.com}$ (dostęp 21.06.2011).

15 Ibidem. 
że po raz pierwszy spróbowała alkoholu w wieku 16-18 lat, aż 33,8\% piło alkohol w wieku 13-15 lat. Podobną opinię można zbudować na podstawie badania przeprowadzonego w Polsce przez WHO w 2000 roku, w którym stwierdzono, że już 11-15-letni uczniowie w Polsce podejmują próby picia alkoholu. ${ }^{16}$

Kolejnym rozpoznaniem problemu dotyczącym spożycia alkoholu jest badanie „Konsumpcja substancji psychoaktywnych przez młodzież szkolną - Młodzież 2008” zrealizowane w październiku 2008 roku na zlecenie Krajowego Biura ds. Przeciwdziałania Narkomanii wśród młodzieży uczęszczającej do ostatnich klas szkół ponadgimnazjalnych. Wyniki tego badania zaprezentowane są w tabeli 2.

Wywiady z uczniami $(\mathrm{N}=1400)$ przeprowadzone metodą audytoryjną wskazały, że napoje alkoholowe są używką bardziej rozpowszechnioną niż papierosy czy narkotyki. ${ }^{17}$ Ponadto aktualne badania nie wskazują czynników społeczno-demograficznych różnicujących młodzież w kwestii spożywania alkoholu. Co do spożycia różnych typów alkoholi, to zgodnie z tym badaniem systematycznie rośnie zwłaszcza konsumpcja piwa. Liczba młodzieży, która deklaruje, że nigdy nie piła piwa, obniżyła się z 47\% w 1992 roku do 22\% w 2008 roku. Rośnie też liczba respondentów, którzy deklarują, co jest szczególnie niepokojące, prawie codzienne spożycie tego typu alkoholu - z 10\% w 1992 roku do 25\% w 2008 roku. W ostatnich latach można obserwować zjawisko zwiększonej sprzedaży piwa. Przyczyna tkwi w niskiej stosunkowo cenie tego artykułu, jak również pewnej modzie i społecznym przyzwoleniu na jego konsumpcję. ${ }^{18}$

Odnosząc się do danych zawartych w tabeli 2, można ponadto stwierdzić, że spośród różnych typów alkoholi wino cieszy się stosunkowo najmniejszym zainteresowaniem wśród polskiej młodzieży szkolnej. Całkowity brak kontaktu z tym typem alkoholu w 1992 roku deklarowało 59\% badanych, a w 2008 roku już 67\%. Natomiast niemal codzienne spożycie wina utrzymuje się w ciągu tych lat niezmiennie na poziomie $2 \%$.

W 1992 roku brak kontaktu z wódką deklarowało niemal trzy czwarte badanej młodzieży (69\%), a w 2008 roku - już mniej niż połowa (42\%). ${ }^{19}$ Szczególnie groźny

16 http://www.parpa.pl (dostęp 25.08.2011).

17 „Opinie i Diagnozy CBOS” 2009 nr 13.

${ }^{18}$ Młodzież, która nie pije piwa, uczęszcza głównie do publicznych i prywatnych liceów ogólnokształcących (odpowiednio 27\% i 25\%); najmniej uczniów niepijących piwa uczęszcza do zasadniczych szkół zawodowych (14\%). Piwo jest także popularniejsze wśród uczniów uważających się za dwójkowych i trójkowych (80\%) niż w grupie uczniów piątkowych i szóstkowych (56\%). Ponadto po piwo częściej sięga młodzież wielkomiejska: $w$ miastach $\mathrm{z}$ więcej niż 500 tys. mieszkańców alkoholu nie pije jedynie $16 \%$ uczniów, podczas gdy na wsi i w małych miastach, liczących do 20 tys. mieszkańców, odsetek niepijących wynosi $24 \%$.

${ }^{19}$ Wynik taki jest po części efektem stosowania dość ogólnej kategorii „wódka i inne mocne alkohole”, która obejmuje wiele rodzajów alkoholu, a po części wiąże się z różnymi wzorami picia mocnych trunków, nie tylko jako czystego alkoholu, a po części wiąże się z różnymi wzorami picia mocnych trunków, nie tylko 
wydaje się też być wzrost konsumpcji wódki i to raz w tygodniu, 2-3 razy, 4-5 razy oraz 6 i więcej razy w tygodniu. Odpowiednio z 10\% w 1992 roku do 19\% w 2008 roku, z 7\% w 1992 roku do 20\% w 2008 roku, z 3\% w 1992 roku do 8\% w 2008 roku oraz z 2\% w 1992 roku do 6\% w 2008 roku. Są to wzrosty 2- i 3-krotne kontaktu młodzieży z mocnymi typami alkoholi (tabela 2).

Tabela 2. Spożycie alkoholu przez młodzież w Polsce w latach 1992-2008 (w \%)

\begin{tabular}{|c|c|c|c|c|c|c|}
\hline \multirow{2}{*}{$\begin{array}{l}\text { Czy w ciągu ostatniego miesiąca } \\
\text { pite(a)ś piwo, wino lub wódkę? }\end{array}$} & \multicolumn{3}{|c|}{ Badania CBOS } & \multirow{2}{*}{$\frac{\text { Badanie IPiN }}{1999}$} & \multicolumn{2}{|c|}{ Badania KBPN } \\
\hline & 1992 & 1994 & 1996 & & 2003 & 2008 \\
\hline \multicolumn{7}{|l|}{ Piwo } \\
\hline Ani razu & 47 & 40 & 31 & 25 & 15 & 22 \\
\hline $1 \mathrm{raz}$ & 8 & 10 & 11 & 13 & 10 & 10 \\
\hline 2-3 razy & 11 & 18 & 18 & 22 & 22 & 23 \\
\hline $4-5$ razy & 7 & 10 & 14 & 14 & 15 & 14 \\
\hline 6 i więcej razy & 10 & 18 & 23 & 20 & 24 & 25 \\
\hline Tak, bez podania ile razy & 13 & 3 & 2 & 2 & 5 & 3 \\
\hline Brak danych & 4 & 1 & 1 & 4 & 9 & 3 \\
\hline \multicolumn{7}{|l|}{ Wino } \\
\hline Ani razu & 59 & 59 & 66 & 75 & 44 & 67 \\
\hline $1 \mathrm{raz}$ & 16 & 17 & 14 & 12 & 12 & 13 \\
\hline $2-3$ razy & 11 & 15 & 13 & 7 & 10 & 10 \\
\hline $4-5$ razy & 3 & 4 & 3 & 3 & 4 & 3 \\
\hline 6 i więcej razy & 2 & 4 & 3 & 2 & 4 & 2 \\
\hline Tak, bez podania ile razy & 6 & 1 & 1 & 1 & 2 & 1 \\
\hline Brak danych & 3 & - & - & - & 24 & 4 \\
\hline \multicolumn{7}{|l|}{ Wódka } \\
\hline Ani razu & 69 & 53 & 53 & 54 & 29 & 42 \\
\hline $1 \mathrm{raz}$ & 10 & 18 & 17 & 17 & 17 & 19 \\
\hline 2-3 razy & 7 & 15 & 16 & 16 & 21 & 20 \\
\hline $4-5$ razy & 3 & 7 & 6 & 5 & 7 & 8 \\
\hline 6 i więcej razy & 2 & 5 & 6 & 5 & 6 & 6 \\
\hline Tak, bez podania ile razy & 6 & 2 & 1 & 3 & 2 & 1 \\
\hline Brak danych & 3 & - & 1 & - & 18 & 4 \\
\hline
\end{tabular}

Źródło: „Opinie i Diagnozy CBOS” 2009 nr 13, s. 24.

jako czystego alkoholu, ale także w tzw. drinkach, samodzielnie przygotowywanych wieloskładnikowych koktajlach czy gotowych napojach z dodatkiem wódki lub rumu, coraz powszechniej dostępnych w sklepach. 
Tabela 3. Częstotliwość spożycia wina przez respondentów w podziale na płeć (w \%)

\begin{tabular}{|l|c|c|}
\hline \multicolumn{1}{|c|}{ Wyszczególnienie } & Kobieta & Mężczyzna \\
\hline Tak, codziennie & 0,8 & 2,5 \\
\hline Raz na kilka dni & 2,0 & 5,9 \\
\hline Sporadycznie na imprezach & 33,6 & 30,1 \\
\hline Raz spróbowałem i na tym koniec & 21,1 & 19,7 \\
\hline Nigdy nie próbowałem & 42,5 & 41,8 \\
\hline Ogółem & 100,0 & 100,0 \\
\hline
\end{tabular}

Źródło: Obliczenia własne na podstawie badań terenowych.

Alkoholizm jest istotną plagą społeczną w Polsce. Fakt ten potwierdzają badania przeprowadzone nad postawami i zachowaniami zdrowotnymi młodzieży w 2004 roku. Badaniem objęta była młodzież trzecich klas gimnazjów ze szkół promujących zdrowie i szkół tradycyjnych w całej Polsce. Liczebność próby wyniosła 502 uczniów, w tym 252 dziewcząt i 241 chłopców. Badanie poprzedzono pilotażem. ${ }^{20}$

\subsection{Ryzykowne postawy seksualne $i$ ich konsekwencje}

\subsubsection{Prostytucja}

Prostytucja (łac. pro - przed, statuere - wystawiać) oznacza wystawić na widok, umieścić na przodzie, czyli oddanie własnego ciała do dyspozycji większej liczbie osób w celu osiągnięcia przez nie zadowolenia seksualnego i pobieranie za to wynagrodzenia materialnego. ${ }^{21}$ Przy prostytucji ma więc miejsce świadczenie usług seksualnych (polegających zwykle na odbywaniu stosunków płciowych) za pieniądze lub inne korzyści materialne. ${ }^{22}$

Prostytucja jest jedną z branż tzw. przemysłu związanego z seksem (sex industry). Całkowita wartość rynku prostytucji oceniana jest na przeszło 187 mld dol. Duża

${ }^{20}$ Badane wyniki poddano analizie ilościowej pod kątem istotności różnic statystycznych między dziewczętami i chłopcami w zestawieniu z badanymi cechami. Zasadniczą miarą przy badaniu zależności stochastycznej jest test niezależności chi-kwadrat. Na jego podstawie dokonano oceny siły zależności, korzystając ze współczynnika zbieżności Cramera (Vc). Natomiast różnice w częstościach między chłopcami a dziewczętami były badane z wykorzystaniem testu istotności U dla wyodrębnionych parametrów.

21 Osoba oferująca usługi seksualne nazywana jest prostytutką; termin ten odnosi się również do mężczyzn (męska prostytutka).

${ }^{22}$ http://pl.wikipedia.org/wiki/Prostytucja (dostęp 27.08.2011). 
część tej wartości przypada na Azję, mimo że w zdecydowanej większości państw azjatyckich prostytucja jest nielegalna. ${ }^{23}$

W latach siedemdziesiątych i osiemdziesiątych w Europie Zachodniej odnotowano wzmożenie działań publicznych wśród osób trudniących się prostytucją. Działania te miały na celu polepszenie warunków ich działalności i wywalczenie sobie korzystnych praw. Pojawiały się protesty ze strony tych grup i powstawały nowe organizacje zrzeszające osoby prostytuujące się. ${ }^{24}$ Działania kobiet zaowocowały powstaniem międzynarodowej organizacji International Committee for Prostitues' Rights (ICPR). Organizacja ta odznaczyła się dużą skutecznością w walce o prawa kobiet trudniących się prostytucją. Już w 1986 roku Parlament Europejski podjął uchwałę, która wzywała władze członkowskie m.in. do niekaralności prostytucji jako zawodu, zagwarantowania prostytutkom takich samych praw jak innym obywatelom, zapewnienia im ochrony niezależności, zdrowia i bezpieczeństwa.

W Polsce w latach dziewięćdziesiątych XX wieku nastąpił rozwój szeroko rozumianego seks biznesu. ${ }^{25}$ Liczba zarejestrowanych agencji towarzyskich wynosiła około 750, a „Businessman Magazine” ocenił wówczas wartość polskiego rynku związanego z seks biznesem na 5 do 10 mld zł. Powstawały sex shopy, lokale ze striptizem i tzw. agencje towarzyskie. Szacuje się, że w Polsce szeroko rozumiane, płatne usługi seksualne świadczyło od 18 do 20 tys. osób (inne źródła podają, że liczba ta wynosi nawet 150-160 tys. osób, a liczba agencji towarzyskich około 15 tys.) W agencjach towarzyskich poza Polkami (72\%) pracują głównie kobiety zza wschodniej granicy Polski: Ukrainki, Rosjanki, Białorusinki i Bułgarki.

Zjawisko prostytucji było w Polsce badane m.in. przez OBOP. Z badań wynika, że od lat dziewięćdziesiątych wzrastał poziom tolerancji Polaków dla prostytucji oraz spadała liczba osób deklarujących potępienie z tego powodu. Stwierdzenie to potwierdzają opinie respondentów. I tak w 1993 roku tolerancję w tym zakresie deklarowało 17\% ankietowanych, w 1995 roku - 18\%, a w 2001 roku już 39\%. Nie zmienił się szczególnie stosunek do legalizacji prostytucji: za legalizacją prostytucji w 1997 roku było 78\% mężczyzn i 50\% kobiet, a w 2001 roku 74\% mężczyzn i 51\% kobiet. W 2001 roku ankietowani Polacy w 38,5\% uważali, że domy publiczne powinny działać legalnie, w 23,9\% - raczej legalnie; w 15,4\% - że raczej powinny być zakazane, a w $16,7 \%$ - że powinny być zakazane. W innym pytaniu stwierdzili,

23 Do grupy tej należą: Gruzja, Azerbejdżan, Afganistan, Uzbekistan, Tadżykistan, Pakistan, Turkmenistan, Bahrajn, Birma, Brunei, Irak, Iran, Jordania, Kuwejt, Malediwy, Katar, Arabia Saudyjska, Sri Lanka, Syria, Zjednoczone Emiraty Arabskie, Jemen, Oman, terytoria palestyńskie, Nepal, Bhutan, Mongolia, Chiny, Tajwan, Korea Północna i Południowa.

${ }_{24}$ I tak np. w 1976 roku około 150 prostytutek z Lyonu protestowało przeciwko obojętności władz wobec problemów bytowych prostytutek i brutalności policji.

25 W 1996 roku było zarejestrowanych 300 agencji towarzyskich. 
że agencje towarzyskie są zdecydowanie potrzebne - w 6,9\%, potrzebne - w 19,2\%; raczej potrzebne $-\mathrm{w} 30 \% .{ }^{26}$

\section{Rysunek 1. Prostytucja legalna i regulowana w Europie}

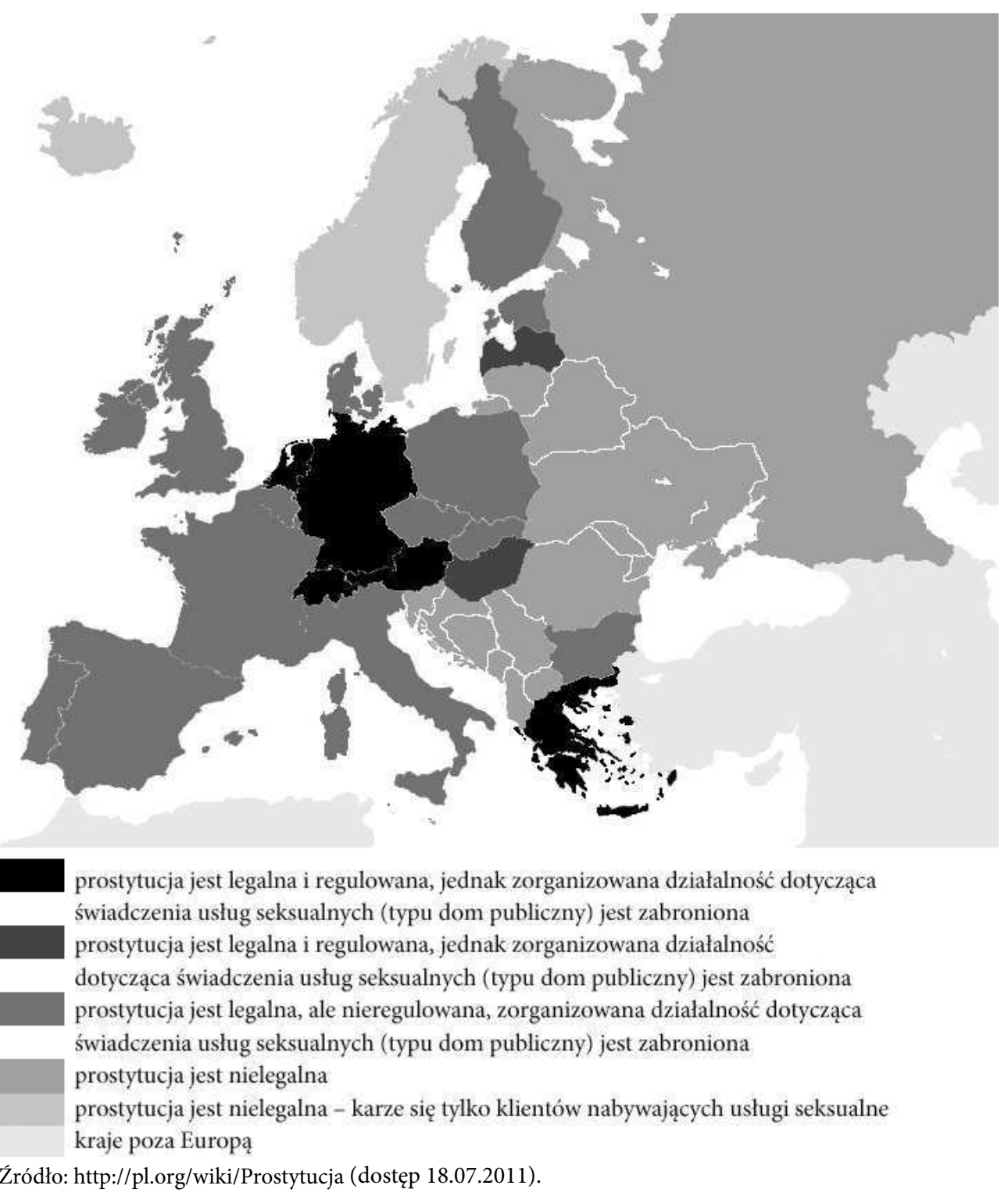

${ }^{26} \mathrm{http} / / /$ katalog.wp.pl/opinia-publiczna-badania/ (dostęp 21.06.2011). 
Jak wynika z innego badania OBOP w 2003 roku, przyczyną podejmowania się prostytucji w Polsce była trudna sytuacja materialna, którą deklarowało $60 \%$ respondentów. ${ }^{27}$ Możliwość zarobku i osiągnięcia zysku była w $17 \%$ przyczyną prostytucji, a chęć podwyższenia standardu życia była deklarowana w 14\%. Spośród uczestniczek badań $67 \%$ wskazało, że prostytucja była zasadniczym źródłem utrzymania, a $12 \%$ stwierdziło, że dochody uzyskiwane z innego niż prostytucyjne źródło zarobkowania byłyby wystarczające do przeciętnego życia. Liczną grupę prostytuujących się kobiet stanowiły studentki, które zarobione pieniądze przeznaczały na finansowanie nauki lub utrzymanie się. Cztery respondentki-studentki deklarowały, że wspomagają finansowo rodziców. W kilkunastu przypadkach studentki lub młode pracownice deklarowały, że posiadają jednego głównego klienta (zwykle dobrze sytuowanego mężczyznę w wieku 40-55 lat). Chociaż z innych badań nad prostytucją w Polsce (badań policji z Warszawy i w kilku miejscowościach województwa podlaskiego oraz mazowieckiego wśród 103 prostytutek) wynika, że aż 6,8\% deklarowało sytuację rodziny jako bardzo dobrą, 10,7\% - jako dobrą, 33,0\% - jako przeciętną, $27,2 \%$ - jako trudną, a tylko $21 \%$ - jako bardzo trudną.

Prostytucją zajmuje się coraz więcej osób nieletnich (poniżej 18. roku życia). W innych badaniach, polegających na wykonaniu 100 telefonów do stołecznych i podwarszawskich agencji z pytaniem: „Czy znajdziemy u was dziewczyny w wieku 16-18 lat?” uzyskano twierdzące odpowiedzi: 42 razy w 2003 roku, 64 razy w 2004 roku, 79 razy w 2005 roku.

Wracając do badania OBOP z 2003 roku, tylko niecałe 3\% respondentek stwierdziło, że są zmuszane do prostytuowania się. Niewiele ponad $2 \%$ kobiet motywowało własny wybór ciekawością, przypadkiem, narkotykami lub ucieczką z domu. Prawie 2/3 badanych kobiet traktowało świadczenie usług seksualnych jako zajęcie tymczasowe, które pozwoli wyjść z bieżących kłopotów. ${ }^{28}$

W badanej grupie występowało duże zróżnicowanie okresu prostytuowania się: $20 \%$ powyżej 3 lat, $43 \%$ - od roku do 3 lat, 17\% - do roku, z tego $9 \%$ okazjonalnie. Wśród badanych osób $50 \%$ prostytuowało się raz w tygodniu lub kilka razy w tygodniu, zwykle w weekendy, 12\% - codziennie, 14\% - kilka razy w miesiącu, $7 \%$ raz w miesiącu. Planowany okres dalszego uprawiania prostytucji wynosił głównie od 1 do 3 lat (36\%) oraz do roku (27\%). Jedno z pytań dotyczyło stanu cywilnego i związanych z nim planów. W odpowiedzi okazało się, że 76\% kobiet było pannami,

\footnotetext{
${ }^{27}$ Średnie stawki za godzinę towarzystwa wahają się od 100 do 300 zl, choć zdarza się, że klienci pozostawiają napiwki. W badaniach przeprowadzonych przez OBOP przeciętne dochody miesięczne netto osób świadczących usługi seksualne wynosiły: do 1 tys. zł - 37\% ankietowanych, od 1 tys. do 2 tys. zł - 31\% ankietowanych, powyżej 2 tys. $\mathrm{zl}-26 \%$ ankietowanych.

${ }^{28}$ www.tnsglobal.pl/abin/r/1475/TNS-OBOP_dlaczego-prostytucja.doc (dostęp 07.08.2011).
} 
z czego $100 \%$ zamierzało zawrzeć związek małżeński, 14\% było mężatkami i $10 \%$ - rozwódkami (istotny odsetek z nich miał więc rodziny i dzieci). W kolejnym pytaniu o stosunek do wiary aż $80 \%$ stwierdziło, że uważa się za osoby religijne. Co do wykształcenia, to $10 \%$ miało wykształcenie podstawowe, $23 \%$ - zasadnicze, $34 \%$ - średnie, 29\% - wyższe.

Jak wynika $z$ badań prowadzonych wśród osób prostytuujących się, w Polsce z usług seksualnych korzystają osoby wywodzące się z licznych grup społecznych (w tym turyści zagraniczni). W badaniach przeprowadzonych na grupie Polaków w 2005 roku korzystanie z płatnych usług seksualnych zadeklarowało w sumie 12\% badanych mężczyzn i niespełna 1\% kobiet (najwięcej badanych, którzy korzystali $\mathrm{z}$ usług seksualnych, mieszkało $\mathrm{w}$ województwach pomorskim i łódzkim - 17\% oraz $\mathrm{w}$ mazowieckim - 16\%, najmniej w województwie podkarpackim - 4,8\%). Największy odsetek mężczyzn, którzy w jakichkolwiek okolicznościach korzystali z płatnych usług seksualnych, odnotowano wśród osób w wieku 25-29 lat, z wyższym wykształceniem (14\%), mieszkających w dużych miastach, tj. powyżej 500 tys. mieszkańców (15\%).

\subsubsection{Zarażenia HIV i AIDS}

Wirus niedoboru odporności, HIV (human immunodeficiency virus), pochodzi z rodziny retrowirusów. Wywołuje on AIDS, czyli zespół nabytego niedoboru (upośledzenia) odporności (acquired immunodeficiency syndrome lub acquired immune deficiency syndrome) - końcowe stadium zakażenia HIV cechującego się wyniszczeniem układu odpornościowego, co skutkuje zapadalnością na liczne choroby, np. nowotwory czy zapalenia płuc mogące zakończyć się śmiercią pacjenta.

W Polsce tylko w styczniu 2011 roku zarejestrowano 308 nowo wykrytych zakażeń HIV, z czego wśród mężczyzn 151, a wśród kobiet 33. Natomiast w przypadku AIDS zarejestrowano w tym okresie 8 przypadków wśród mężczyzn i 3 zachorowania wśród kobiet (tabela 4).

Tabela 4. Liczba nowych przypadków zarejestrowanych w okresie 1-31.01.2011 roku według płci i wieku

\begin{tabular}{|l|r|r|r|r|r|r|r|r|r|}
\hline \multirow{2}{*}{$\begin{array}{c}\text { Wiek } \\
\text { w latach }\end{array}$} & \multicolumn{4}{|c|}{ HIV } & \multicolumn{4}{c|}{ AIDS } & \multicolumn{3}{c|}{ Zgony } \\
\cline { 2 - 11 } & M & K & b.d. & M & K & b.d. & M & K & b.d. \\
\hline Niemowlęta & - & - & - & - & - & - & - & - & - \\
\hline $1-14$ & - & - & - & - & - & - & - & - & - \\
\hline $15-19$ & 2 & - & - & - & - & - & - & - & - \\
\hline $20-29$ & 44 & 9 & 26 & - & 1 & - & - & - & - \\
\hline
\end{tabular}




\begin{tabular}{|l|r|r|r|r|r|r|r|r|r|}
\hline \multirow{2}{*}{$\begin{array}{c}\text { Wiek } \\
\text { w latach }\end{array}$} & \multicolumn{4}{|c|}{ HIV } & \multicolumn{4}{c|}{ AIDS } & \multicolumn{3}{c|}{ Zgony } \\
\cline { 2 - 12 } & M & K & b.d. & M & K & b.d. & M & K & b.d. \\
\hline $30-39$ & 53 & 11 & 39 & 5 & 1 & - & 1 & 1 & - \\
\hline $40-49$ & 33 & 8 & 19 & 3 & - & - & 1 & - & - \\
\hline $50-59$ & 11 & 3 & 8 & - & 1 & - & - & 1 & - \\
\hline $60+$ & 4 & - & - & - & - & - & - & - & - \\
\hline Brak danych & 4 & 2 & 30 & - & - & - & - & - & - \\
\hline Razem & 151 & 33 & 124 & 8 & 3 & - & 2 & 2 & - \\
\hline
\end{tabular}

Źródło: http://www.pzh.gov.pl/oldpage/epimeld/hiv_aids/2011.htm (dostęp 11.09.2011).

Jak wynika z tabeli 5, w ciągu stycznia 2011 roku przyczyną zakażenia HIV w Polsce były głównie kontakty seksualne między mężczyznami oraz używanie narkotyków w iniekcjach. Przypadki te dotyczą przede wszystkim mężczyzn, bowiem zakażonych mężczyzn tylko w okresie miesiąca w 2011 roku było blisko 5-krotnie więcej niż kobiet.

Tabela 5. Liczba przypadków zarejestrowanych w okresie 1-31.01.2011 roku według prawdopodobnej drogi transmisji

\begin{tabular}{|l|c|c|c|}
\hline \multicolumn{1}{|c|}{ Grupa ryzyka } & HIV & AIDS & Zgony \\
\hline Mężczyźni utrzymujący kontakty seksualne z mężczyznami & 65 & 3 & 2 \\
\hline Stosujący narkotyki w iniekcjach & 8 & 4 & - \\
\hline Chorzy na hemofilię & - & - & - \\
\hline Biorcy krwi & - & - & - \\
\hline Utrzymujący ryzykowne kontakty heteroseksualne & 3 & 2 & - \\
\hline Dzieci matek zakażonych HIV & - & - & - \\
\hline Zakażenia jatrogenne & - & - & - \\
\hline Inni/brak danych & 232 & 2 & 2 \\
\hline Razem & 308 & 11 & 4 \\
\hline
\end{tabular}

Źródło: http://www.pzh.gov.pl/oldpage/epimeld/hivaids/2011.htm (dostęp 11.09.201).

Częstość zakażeń HIV jest wyższa wśród mężczyzn niż wśród kobiet, ale od 1985 roku odsetek zakażonych kobiet stale wzrasta i wykazuje duże zróżnicowanie w poszczególnych krajach europejskich. Polskie dane również odzwierciedlają tę tendencję. Należy jednak dodać, że oficjalne dane na temat zachorowalności na AIDS w naszym kraju są niepełne. Występujące w Polsce silne odrzucenie nosicieli wirusa HIV oraz chorych na AIDS zniechęca do wykonywania testów diagnostycznych oraz upubliczniania informacji o jego rezultacie. Naznaczenie społeczne nie jest tak silne w odniesieniu do innych chorób przenoszonych drogą płciową, jak 
w przypadku AIDS. ${ }^{29}$ Ponadto zakażenie lub zachorowanie bardziej piętnuje kobiety niż mężczyzn. Jest to związane ze społecznymi rolami kobiet i mężczyzn. Kobietom wyznacza się rolę osoby panującej nad własnymi popędami, podporządkowanej inicjatywie partnera oraz zależnej od preferowanych przez niego zachowań seksualnych. Wokół HIV/AIDS wytworzono szereg stereotypów, a wiedza na ten temat w polskim społeczeństwie jest niska.

Ogólnie, jeśli chodzi o zachorowalność na AIDS, duży wzrost dotyczy kobiet w wieku 20-29 lat oraz mężczyzn w wieku do 19 lat. Są też takie informacje, które wykazują tendencję spadkową. Między 2000 a 2005 rokiem były to kobiety w przedziale wieku 0-19 oraz 40-49 lat oraz mężczyźni w wieku 20-29 i 30-39 lat (tabela 6).

Tabela 6. Zachorowalność na AIDS według płci i wieku w latach 2000 i 2005

\begin{tabular}{|l|c|c|c|c|}
\hline \multirow{2}{*}{ Wiek } & \multicolumn{2}{|c|}{ Kobiety } & \multicolumn{2}{c|}{ Mężczyźni } \\
\cline { 2 - 5 } & 2000 & 2005 & 2000 & 2005 \\
\hline Ogółem & 0,14 & 0,17 & 0,52 & 0,57 \\
\hline $0-19$ & 0,08 & 0,04 & 0,02 & 0,04 \\
\hline $20-29$ & 0,28 & 0,38 & 0,81 & 0,71 \\
\hline $30-39$ & 0,33 & 0,44 & 1,67 & 1,59 \\
\hline $40-49$ & 0,26 & 0,21 & 0,82 & 0,83 \\
\hline $50-59$ & - & 0,07 & 0,20 & 0,55 \\
\hline 60 lat i więcej & - & - & - & 0,12 \\
\hline
\end{tabular}

Źródło: Kobiety w Polsce, GUS, Zakład Wydawnictw Statystycznych, Warszawa 2007, s. 90.

Problem AIDS i HiV ma silny związek z prostytucją, która w Polsce jest nielegalna. Mimo że większość prostytutek pracujących w agencjach towarzyskich, tzn. około $80 \%$, otrzymało od właścicieli agencji skierowanie na badania (lub oczekiwano od nich takiego zaświadczenia) w celu wyeliminowania nosicielstwa HIV i chorób wenerycznych (miały one również zapewnione okresowe kontrole u lekarzy świadczących usługi na rzecz agencji), to związek między zakażeniem HIV a uprawianiem prostytucji jest duży. Badane osoby powszechnie odrzucały argument zagrożenia wirusem HIV, wskazując na wystarczające zabezpieczenie w postaci dbania o higienę. Tym niemniej choroby te były wymieniane jako jedno z zagrożeń obok obaw związanych z wykluczeniem społecznym.

29 A. Giddens, Sociology, Polity Press, Oxford 1990, s. 193. 


\subsection{Narkomania i nikotynizm}

Narkomania (z grec. narke - odurzenie, mania - szaleństwo) - potoczne określenie odnoszące się do uzależnienia od substancji chemicznych wpływających na pracę mózgu.

Narkomania charakteryzuje się:

- tzw. głodem narkotycznym,

- przymusem zażywania środków odurzających,

- chęcią zdobycia narkotyku za wszelką cenę i wszystkimi sposobami.

Badania nad zasięgiem narkomanii wśród młodzieży w Polsce wykonane przez Instytut Psychiatrii i Neurologii w latach 1995, 1999, 2003 i 2007 w ramach Europejskiego Programu Badań Szkolnych nad Używaniem Alkoholu i Narkotyków przez Młodzież (ESPAD) oraz badania populacji generalnej zrealizowane przez Krajowe Biuro ds. Przeciwdziałania Narkomanii w latach 2002 i 2006 pokazały, że w 1995 roku chociaż raz w ciągu całego życia używało tych substancji 10,1\% uczniów trzecich klas gimnazjów, a w 2003 roku już 19,2\% (rysunek 3). W latach 1999-2003 obserwowany był silny wzrost liczby młodzieży zażywającej narkotyki. Mimo to zdecydowana większość respondentów deklarowała, że nigdy nie korzystała z substancji psychoaktywnych.

Rysunek 2. Uczniowie gimnazjów w wieku 15-16 lat, którzy używali przetworów konopi w latach 1995, 1999, 2003 i 2005

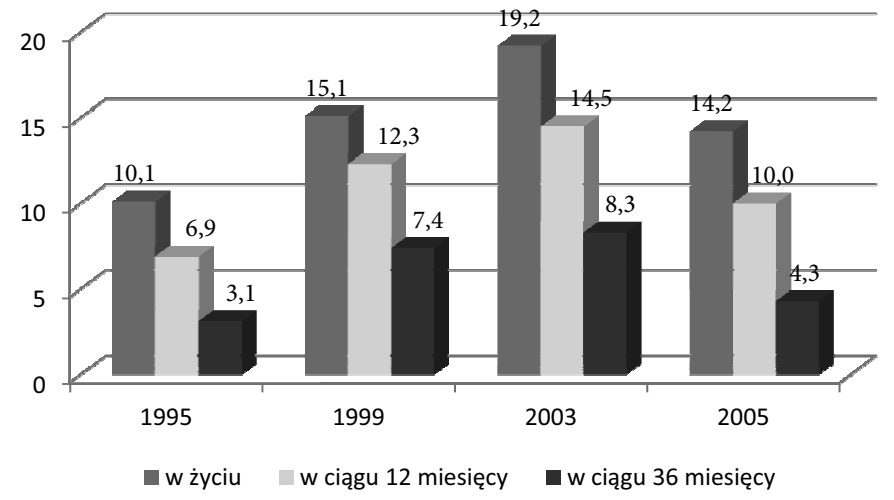

Źródło: http://www.narkomania.gov.pl/epidemiologia.htm (dostęp 6.10.2011) 
Rysunek 3 wykazuje niższe zażywanie narkotyków w 2006 roku w porównaniu z 2002 rokiem przez młodzież w wieku 16-24 z 10\% do 9\%, natomiast wzrost spożycia w grupie wiekowej $35-44$ lat z $0 \%$ do $2 \%$.

\section{Rysunek 3. Używanie jakiejkolwiek substancji psychoaktywnej w czasie 12 miesięcy według wieku (w \%)}

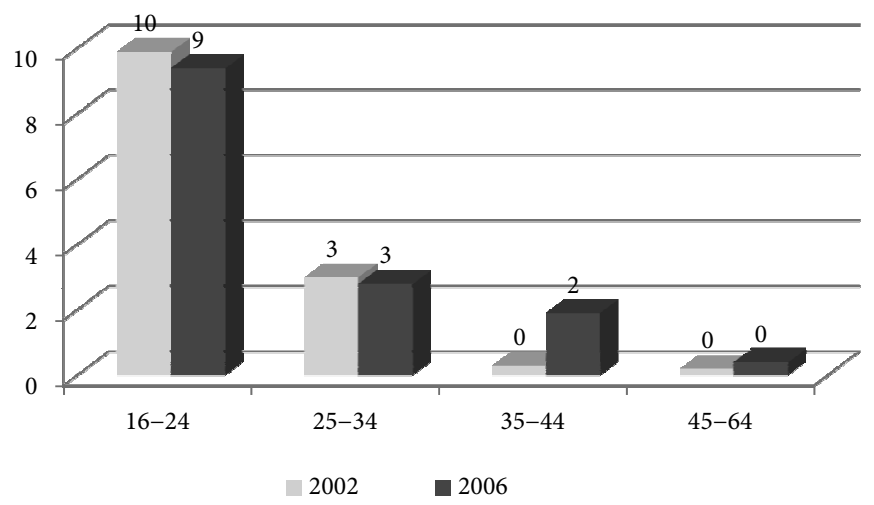

Źródło: http://www.narkomania.org.pl/czytelnia/86 (dostęp 3.08.2011).

W przywoływanym już badaniu przeprowadzonym nad postawami i zachowaniami zdrowotnymi młodzieży szkół gimnazjalnych stwierdzono, że podobnie jak w przypadku innych używek, w tym różnego typu alkoholi, chłopcy znacznie częściej sięgają po narkotyki. Jest to szczególnie widoczne w odpowiedzi na pytanie dotyczące spożycia „sporadycznie na imprezach”: dziewczynki - 3,2\%, chłopcy - 5,9\% oraz „nigdy nie próbowałem” odpowiednio $89,1 \%$ oraz $83,5 \%$ (tabela 7 ). W obu tych przypadkach odnotowane są istotne zależności statystyczne przy poziomie istotności odpowiednio 0,13 i wyższym oraz 0,04 i wyższym.

Tabela 7. Częstotliwość zażywania narkotyków według płci (w \%)

\begin{tabular}{|l|c|c|}
\hline \multicolumn{1}{|c|}{ Wyszczególnienie } & Kobieta & Mężczyzna \\
\hline Tak, codziennie & 1,2 & 1,3 \\
\hline Raz na kilka dni & 2,0 & 2,1 \\
\hline Sporadycznie na imprezach & 3,2 & 5,9 \\
\hline Raz spróbowałem i na tym koniec & 4,4 & 7,2 \\
\hline Nigdy nie próbowałem & 89,1 & 83,5 \\
\hline Ogółem & 100,0 & 100,0 \\
\hline
\end{tabular}

Źródło: Obliczenia własne na podstawie badań terenowych. 


\section{Podsumowanie}

Wykluczenie społeczne polega na ograniczaniu zwyczajowej i społecznie akceptowanej drogi życiowej. W rezultacie dana jednostka czy grupa nie może w pełni uczestniczyć w działaniach obywateli danego społeczeństwa, przy czym ograniczenie to nie wynika $\mathrm{z}$ ich osobistych przekonań, ale jest narzucone $\mathrm{z}$ zewnątrz.

$\mathrm{Na}$ wzrost wykluczenia społecznego mogą wpływać liczne aspekty życia społecznego, którymi są alkoholizm, prostytucja czy narkomania. Szczególnie niepokojącym zjawiskiem w Polsce jest wzrost alkoholizmu wśród młodzieży. Wagę problemu potwierdzają np. badania przeprowadzone w Polsce przez WHO w 2009 roku, w których stwierdzono, że już 11-15-letni uczniowie w Polsce podejmują próby picia alkoholu.

Prostytucja to kolejne zjawisko społeczne mające negatywny wpływ na rozwój wykluczenia społecznego. Najczęstszą przyczyną prostytucji w Polsce jest trudna sytuacja materialna, a następnie brak możliwości otrzymania pracy. Jednakże, co zostało potwierdzone przez badania, od lat dziewięćdziesiątych wzrasta poziom tolerancji Polaków dla prostytucji oraz spada liczba osób deklarujących potępienie $\mathrm{z}$ tego powodu. Wskazuje to na społeczne przyzwolenie na szerzenie się prostytucji.

Kolejnym negatywnym zjawiskiem, które może wpływać na wzrost wykluczenia społecznego, jest narkomania. Narkomania w Polsce zatacza coraz szersze kręgi. Zjawisko to dotyczy głównie młodzieży i ma zasięg ogólnokrajowy. Z zażywaniem narkotyków łączy się problem przestępstw popełnianych pod wpływem środków odurzających. Fakt ten potwierdzają badania wskazujące na zwiększanie się liczby wyroków skazujących na karę pozbawienia wolności z powodu licznych przestępstw popełnianych pod wpływem narkotyków.

O randze narkomanii wśród problemów społecznych decydują nie tylko parametry ilościowe, ale również dynamika zjawiska i zmiany w strukturze populacji dotkniętej tym problemem. Syntetyczne opracowania z zakresu szerzenia się narkomanii podkreślają narastające tempo zjawiska, wykraczanie jego zasięgu poza grupy i środowiska tradycyjnie kojarzone $\mathrm{z}$ narkomanią. To powoduje, że pomoc narkomanom jest trudna do zrealizowania. 


\section{Alcoholism, prostitution, HIV and AIDS, drug abuse as a form of social exclusion (in terms of research)}

The growth of social exclusion may be affected many aspects of social life such as alcoholism, prostitution and drug addiction. Particularly worrying is the growth of alcoholism among young people in Poland. A 2009 study conducted in Poland by WHO states that 11-15-year-old students in Poland are attempting to drink alcohol.

Prostitution is another social phenomenon affecting the development of social exclusion. The most common cause of prostitution in Poland is difficult financial situation and inability to obtain work.

Another negative phenomenon, which may affect the growth of social exclusion is drug addiction. The reasons for importance of drug abuse among social problems are not only quantitative parameters, but also the dynamics of the phenomena and changes in the structure of the population affected by the problem. Synthetic studies of the spread of drug addiction emphasize that the increasing rate of the phenomenon goes beyond its reach and environmental groups traditionally associated with drug addiction. This is the reason why it is so hard to help the drug addicts.

\section{L'alcoolisme, la prostitution, le VIH et le SIDA, la toxicomanie comme une forme d'exclusion sociale (en termes de recherche)}

Il y a de nombreux aspects de la vie sociale qui peuvent provoquer la croissance de l'exclusion sociale: lalcoolisme, la prostitution et la toxicomanie. L'augmentation de l'alcoolisme chez les jeunes est un phénomène particulièrement préoccupant en Pologne. L'importance de ce problème est confirmée par l'étude menée en Pologne par l'OMS en 2009. Létude montre que les élèves polonais âgés de 11 à 15 ans ont déjà tanté de boire de l’alcool.

La prostitution est un autre phénomène social qui affecte le développement de l'exclusion sociale. Les causes les plus fréquentes de la prostitution en Pologne sont une situation financière difficile et une impossibilité d’obtenir un emploi.

Un autre phénomène négatif, qui influence la croissance de l'exclusion sociale, est la toxicomanie. Son importance parmi les problèmes sociaux ne résulte pas seulement des paramètres quantitatifs, mais elle est également liée à la dynamique 
de ce phénomène et aux changements dans la structure de la population touchée par ce problème. Les études sur la propagation de la toxicomanie soulignent que le rythme de ce phénomène augmente et sa portée s'étend au-delà des groupes et de lenvironnement qui sont traditionnellement liés à la toxicomanie. Cela signifie que l'aide aux toxicomanes est difficile à réaliser. 